\title{
PERANAN NOTARIS DALAM PEMBUATAN PERJANJIAN BUILD OPERATE AND TRANSFER (BOT)
}

\author{
Bagus Yoga Pratama, Fakultas Hukum Universitas Udayana, e-mail: \\ byogapratama22@gmail.com \\ Ibrahim R, Fakultas Hukum Universitas Udayana, e-mail: \\ ibrahim_r@unud.ac.id \\ Desak Putu Dewi Kasih, Fakultas Hukum Universitas Udayana, e-mail: \\ dewi_kasih@unud.ac.id
}

doi: https://doi.org/10.24843/KS.2020.v09.i01.p01

\begin{abstract}
ABSTRAK
Penelitian ini bertujuan untuk menganalisis tentang perkembangan hukum mengenai build operat and transfer (BOT) terkait tahapan dalam proses pembuatan perjanjiannya dan peranan Notaris dalam pembuatan Akta BOT. Jenis penelitian ini adalah penelitian yuridis normatif dengan menggunakan pendekatan perundang-undangan. Sumber bahan hukum yang digunakan terdiri dari bahan hukum primer dan sukunder. Mengenai tehnik penggumpulan bahan hukum menggunakan tehnik bola salju dan metode analisis yang digunakan adalah analisis deskriptif. Hasil dari penelitian ini adalah bahwa dalam pembuatan perjanjian BOT antara pihak Badan Usaha Milik Negara (BUMN) dengan pihak swasta harus melalui beberapa tahap, yakni tahap awal kontrak (prakontrak), tahap kontrak dan tahap selesai kontrak (pasca kontrak). Adapun peranan Notaris pada pembuatan perjanjian BOT adalah sebagai pihak yang ditengah atau netral untuk memberikan saran kepada pihak untuk menuangkan keinginannya dalam bentuk perjanjian.
\end{abstract}

Kata Kunci : perjanjian, Build Operate and Transfer (BOT), dan notaris.

\begin{abstract}
This study aims to analyze the legal developments regarding the making of build operat and transfer (BOT) in the stages of making the agreement and the notary business in making it. This type of research is a normative juridical research using a statutory approach. The resource of legal material is used consists of primary and secondary legal materials. The technique of collecting legal materials using snowball techniques and the analytical method used is descriptive analysis. The results of this research are: first, in making BOT agreements between State-Owned Enterprises (BUMN) and the private sector, it must go through several stages, the initial stage of the contract (pre-contract), the contract stage and the contract completion stage (post-contract). The role of the notary in making the BOT agreement is as a middle or neutral party to provide suggestions to parties to express their wishes in the form of an agreement.
\end{abstract}

Keywords: agreement, Build Operate and Transfer (BOT), and notary.

\section{Pendahuluan}

\subsection{Latar Belakang}

Indonesia merupakan salah satu tujuan destinasi pariwisata. Angka kunjungan wisatawan domestik maupun mancanegara di setiap tahunnya selalu meningkat, hal ini disebabkan karena Indonesia banyak memiliki aset obyek wisata yang menarik dan 
memiliki fasilitas wisata yang cukup mendukung. Berdasarkan Undang-Undang Nomor 10 Tahun 2009 tentang Kepariwisataan (selanjutnya disebut UU Kepariwisataan), Pasal 1 ayat (3) "Pariwisata adalah berbagai macam kegiatan wisata dan didukung berbagai fasilitas serta layanan yang disediakan oleh masyarakat, pengusaha, Pemerintah, dan Pemerintah Daerah."

Guna mendukung fasilitas pariwisata tentu perlu dilakukan pembangunan sarana dan prasarana pariwisata. Salah satu bentuk fasilitas yang banyak diperhatikan oleh para wisatawan adalah akomodasi yang tersedia di daerah tersebut. Pasal 14 ayat (1) huruf (f) UU Kepariwisataan, menentukan bahwa "Usaha pariwisata meliputi penyediaan akomodasi." Selanjutnya pada Pasal 26 huruf (d) menentukan bahwa, "Setiap pengusaha pariwisata berkewajiban memberikan kenyamanan, keramahan, perlindungan keamanan, dan keselamatan wisatawan". Untuk mendukung pariwisata berupa sarana dan prasarana sebagai penunjang pariwisata memang tidak dapat dihindari, selain itu adanya kenyataan bahwa pemerintah mempunyai keterbatasan dalam pembangunan saran dan prasara tersebut, sehingga dibutuhkan kerjasama dengan pihak swasta dalam mewujudkan semua kebutuhan tersebut. Adanya perjanjian yang dibuat pemerintah sebagai penentu kebijakan negara dengan swasta sebagai pihak yang bekerja sama untuk mewujudkan lancarnya pembangunan juga tidak dapat dihindarkan. ${ }^{1}$

Salah satu bentuk perjanjian yang dimaksud adalah perjanjian Build Operate and Transfer (selanjutnya disingkat BOT). Perjanjian ini merupakan salah satu bentuk perjanjian konsesi (hak pengelolaan lahan) yang tentu saja dibatasi oleh jangka waktu tertetu sesuai dengan kesepakatan antara para pihak, dalam pemerintah dengan pihak swasta sebagai Investor. ${ }^{2}$ Perjanjian BOT merupakan alternatif bentuk perjanjian dalam hal pembiayaan proyek yang dilakukan pemerintah guna pengadaan proyek dengan mengundang partisipasi dari pihak swasta dal hal mendesain, menyediakan keuangan, membangun dan mengoperasikan fasilitas untuk kemudian setelah masa konsesi tertentu, kepemilikan ditransfer kepada pemilik tanah atau pemerintah. ${ }^{3}$

Hadirnya swasta dibidang pelayanan infrastruktur yang diadakan oleh pemerintah mengakibatkan munculnya berbagai jenis perjanjian antara pihak swasta dengan pemerintah. Kehadiran tersebut juga merupakan harapan besar bagi pembangunan sebuah negara dalam kaitannya dengan investasi serta peningkatan pelayanan infrastruktur kedepannya. Namun tidak dapat dipungkiri hal tersebut juga mempunyai problematika yang cukup kompleks sebab banyaknya kepentingan dari para pihak yakni swasta dan pemerintah. Satu sisi pemerintah berkeinginan memberikan pelayanan infrastruktur yang terbaik bagi masyarakat sedangkan sisi lain pihak swasta berkeinginan mengeruk keuntungan sebesar-besarnya. ${ }^{4}$

1 Adha, Lalu Hadi. "Kontrak Buld Operate Transfer Sebagai Perjanjian Kebijakan Pemerintah Dengan Pihak Swasta". Jurnal Dinamika Hukum 1, No. 3 (2011): 548.

2 Nurjamil \& Siti Nurhayati. "Build Operate And Transfer Agreements (BOT) On The Use Of Productive Waqf Hak Guna Bangun (HGB) In The National Islamic Economic Law Development" Al-Awqaf: Jurnal Wakaf dan Ekonomi Islam 11, No. 2 (2018): 131.

3 Prabawa, I Gede Abdhi. "Kajian Hukum Terhadap Perjanjian Build Operate And Transfer (BOT) Untuk Melindungi Hak Milik Atas Tanah Dalam Rangka Menunjang Sektor Pariwisata". Kumpulan Jurnal Mahasiswa Fakultas Hukum 1, No. 1 (2014): 2

4 Masitoh, Hidayatul. "Public Private Partnership (PPP) Pengelolaan Aset Daerah: Studi Deskriptif Tentang Kemitraan Antara Perusahaan Daerah Pasar Surya (PDPS) Surabaya Dengan PT Arwinto Intan Wijaya (AIW) Dalam Pembangunan Dan Pengembangan Darmo Trade Centre (DTC) Surabaya." Jurnal Kebijakan Dan Manajemen Publik 2, No. 1 (2014): 2. 
Perjanjian BOT merupakan kerjasama model baru dalam perjanjian, dimana tidak ada peraturan perundang-undangan yang menjelaskan dengan spesifik mengenai pengertian perjanjian ini. Perjanjian BOT Agreement merupakan salah satu dari sekian banyak perjanjian tidak bernama (onbenoemde overeenkomst) yang muncul dengan dilandasi asas kebebasan berkontrak. Asas kebebasan berkontrak di dalam pustakapustaka yang berbahasa Inggris dituangkan dengan istilah "Freedom of Contract" atau "Liberty of Contract" atau "Party Autonomy". Istilah yang pertama lebih umum dipakai daripada yang kedua dan ketiga. Asas kebebasan berkontrak merupakan asas yang universal sifatnya, artinya dianut oleh hukum perjanjian di semua negara pada umumnya. 5

Asas kebebasan berkontrak yang mendasari lahirnya perjanjian BOT, sebagaimana ketentuan Pasal 1338 ayat (1) KUH Perdata yang menentukan, yaitu "Semua persetujuan yang dibuat sesuai dengan undang-undang berlaku sebagai undang-undang bagi mereka yang membuatnya." Perjanjian BOT merupakan perjanjian tidak bernama (onbenoemde overeenkomst), yaitu perjanjian yang tidak diatur secara khusus dalam undang-undang, tetapi tumbuh dan berkembang dalam kegiatan ekonomi Indonesia. Sebagai suatu perjanjian tidak bernama, sampai saat ini belum ada pengertian dan pengaturan secara khusus mengenai pembangunan suatu proyek milik pemerintah ataupun swata yang dibiayai melalui sistem BOT. ${ }^{6}$

Perjanjian BOT memuat hak eksklusif dari seorang pemilik lahan untuk mempersiapkan dan menyerahkan segala keperluan sebelum perjanjian, diantaranya: hasil pengamatan kelayakan, persiapan dari barang dan perlengkapan, pengelolaan dan pengoperasian dari pembangunan serta pembagian hasil kepada investor, yang mana telah diatur undang-undang yang berlaku, kemudian dengan kurun waktu tertentu investor memperoleh penggantian dari segala pembiayaan yang ada selama pembangunan proyek tersebut dengan mengoperasikan, memelihara, dan menerima manfaat ekonomi dari bangunan yang telah ada selanjutnya bangunan dan fasilitas yang melekat diterima kembali oleh pemegang hak ekslusif sebagai pemilik lahan. ${ }^{7}$

Adanya perjanjian BOT, dalam sektor swasta berperan dalam operasional awal diantaranya; pertama desain dan bentuk kerjasama, penyediaan modal atau segala keuangan, skema pembangunan dan pengoperasian dari fasilitas, serta jangka waktu/konsensi tertentu pencapaian target, kedudukan para pihak atas kepemilikan saham selanjutnya akan diteruskan kepada pemerintah pusat atau daerah. Setelah segala keperluan itu terpenuhi, salah satu cara pengembangan proyek-proyek sarana dan prasarana yang menggunakan kerjasama dengan pendanaan dari pihak swasta digunakanlah perjanjian BOT. ${ }^{8}$ Contoh pembangunan sarana yang ada di Jakarta dengan menggunakan sistem BOT ini adalah pembangunan diatas tanah milik negara yang sekarang berdiri adalah Hotel Indonesia, yang mana pembangunan ini

5 Sjahdeini, Sutan Remy. Kebebasan Berkontrak dan Perlindungan yang Seimbang bagi Para Pihak dalam Perjanjian Kredit Bank di Indonesia. (Jakarta: Pustaka Utama Grafiti, 2009), 11.

6 Kamilah, Anita. "Kedudukan Perjanjian Bangun Guna Serah (Build Operate And Transfer/BOT) Dalam Hukum Tanah Nasional". Jurnal Ilmu Hukum Litigasi 15, No.1 (2014): 2157-2158

7 Ibid.

8 Ramadhani, Rahmat. "Konstruksi Hukum Kepemilikan Bangunan Di Atas Tanah Hak Milik Orang Lain Berdasarkan Perjanjian Build Operate And Transfer (BOT)". Jurnal EduTech 4, No. 1 (2018): 27 
melibatkan Badan Usaha Milik Negara PT Hotel Indonesia Natour (Persero) bekerjasama dengan PT Cipta Karya Bumi Indah (CKBI) dan PT Grand Indonesia dalam kurun waktu selama 30 tahun. Berdasarkan penjabaran singkat penulis tertarik untuk melakukan penelitian dari latar belakang diatas, penelitian sederhana dengan mengangkat judul, "Peranan Notaris Dalam Pembuatan Perjanjian Build Operate And Transfer (BOT) Dalam Pembangunan Sebagai Bentuk Pengembangan Pariwisata".

State of the art diambil dari penelusuran beberapa contoh penelitian terdahulu yang digunakan sebagai panduan dan acuan dalam melakukan penelitian ini, yaitu berupa jurnal-jurnal antara lain :

1 Artikel yang ditulis oleh I Gede Abdhi Prabawa yang berjudul "Kajian Hukum Terhadap Perjanjian Build Operate And Transfer (BOT) Untuk Melindungi Hak Milik Atas Tanah Dalam Rangka Menunjang Sektor Pariwisata" pada Kumpulan Jurnal Mahasiswa Fakultas Hukum Volume 1 Nomor 1 tahun 2014 yang meneliti mengenai pengaturan tentang perjanjian build operate and transfer (BOT) beserta keuntungan dan kerugian serta pembagian resiko dari bentuk perjanjian build operate untuk melindungi hak milik atas tanah dalam menunjang industri pariwisata.

2 Artikel yang ditulis oleh Lalu Hadi Adha yng berjudul "Kontrak Build Operate Transfer Sebagai Perjanjian Kebijakan Pemerintah Dengan Pihak Swasta" pada Jurnal Dinamika Hukum Volume 11 Nomor 3 tahun 2011 yang meneliti mengenai pelaksanaan perjanjian dengan pola kontrak Build Operate Transfer (BOT) dan kedudukan antara pemerintah sebagai pengguna jasa dan pihak swasta sebagai penyedia jasa dalam kontrak BOT.

Berdasarkan state of the arts tersebut diatas terdapat perbedaan terhadap apa yang sedang penulis teliti. Pada penelitian ini, penulis meneliti mengenai proses pembuatan perjanjian kerjas sama Build Operate and Transfer (BOT) dan peranan notaris dalam pembuatan perjanjian tersebut, sedangkan pada dua penelitian tersebut diatas meneliti tentang pengaturan perjanjian BOT, beserta keuntungan dan kerugiannya, pelaksanaan perjanjian kontrak BOT dan kedudukan antara pemerintah sebagai pengguna jasa dan pihak swasta sebagai penyedia jasa dalam kontrak BOT. Sehingga berdasarkan perbedaan tersebut, tulisan ini dikaji dalam tulisan yang berjudul "Peranan Notaris Dalam Pembuatan Perjanjian Build Operate And Transfer (BOT)."

\subsection{Rumusan Masalah}

Berdasarkan latar belakang tersebut diatas, maka dapat dikemukakan rumusan masalah yang akan dibahas adalah sebagai berikut:

1. Bagaimana tahap proses pembuatan perjanjian kerja sama Build Operate and Transfer (BOT)?

2. Bagaimana notaris berperan dalam pembuatan perjanjian Build Operate and Transfer (BOT)?

\subsection{Tujuan Penulisan}

Adapun penelitian ini memiliki tujuan umum untuk memahami perkembangan hukum yang ada sekarang tentang penggunaan perjanjian build operate and transfer (BOT), berikutnya memahami peranan notaris berkaitan. Sebagaimana korelasi terhadap tujuan umum, terdapat tujuan yang secara khusus yang ingin diperoleh melalui penelitian ini adalah untuk Mengerti dan memahami mengenai tahap proses pembuatan perjanjian kerja sama Build Operate and Transfer (BOT) serta untuk 
mengetahui peranan notaris apabila pembuatan perjanjian dengan sistem Build Operate and Transfer (BOT).

\section{Metode Penelitian}

Jenis Penelitian ini adalah yuridis normatif artinya penelitian dengan menganalisis bahan kepustakaan hukum yang ada seperti peraturan perundangan yang berlaku, buku yang relevan dengan penelitian, kamus atau ensiklopedia. ${ }^{9}$ Pada penelitian ini menganalisis mengenai proses pembuatan perjanjian kerjas sama Build Operate and Transfer (BOT) dan peranan notaris dalam pembuatan perjanjian tersebut. Adapun pendekatan yang digunakan adalah pendekatan peraturan perundangundangan. Pada penelitian ini menggunakan tehnik bola salju sebagai metode mengumpulkan bahan hukumnya.

\section{Hasil dan Pembahasan}

3.1. Tahap Proses Pembuatan Perjanjian Kerja Sama Build Operate and Transfer (BOT) Antara Badan Usaha Milik Negara (BUMN) dengan Pihak Swasta

Perjanjian BOT digunakan sebagai pemanfaatan dalam kegiatan bisnis pariwisata. Pengaturan BOT mulanya diatur melalui Keputusan Menteri Keuangan No.248/KMK.04/1995 Tentang Perlakuan Pajak Penghasilan terhadap Pihak-pihak yang Melakukan Kerjasama dalam Bentuk Perjanjian Bangun Guna Serah (Build Operate and Transfer). Keputusan Menteri Keuangan tersebut secara tegas hanya mengatur mengenai perpajakan, sedangkan mekanisme perjanjian BOT tidak dijelaskan di dalamnya. Pada tahun 2001, Kementerian Dalam Negeri (Selanjutnya disingkat Kemendagri) mengeluarkan Keputusan Menteri Dalam Negeri dan Otonomi Daerah No. 11 Tahun 2001 tentang Pedoman Pengelolaan Barang Daerah dan di tahun 2016 diubah menjadi Permendagri No. 19 Tahun 2016 tentang Pengelolaa barang milik daerah, namun aturan tersebut tidak spesifik mengatur mengenai BOT.10

Khusus pengaturan kerjasama antara swasta dengan pemerintah melalui skema BOT dilakukan dengan membuat perjanjian yang berlandaskan pada Undang-Undang Nomor 18 Tahun 1999 Tentang Jasa Konstruksi, Peraturan Pemerintah Nomor 6 Tahun 2006 tentang pengelolaan barang milik Negara/Daerah yang kemudian diubah menjadi Peraturan Pemerintah Nomor 38 Tahun 2008, Permendagri Tahun 2007 Tentang pedoman teknis pengelolan barang milik daerah, dan Peraturan Menteri Keuangan Nomor 96 Tahun 2007 tentang tata cara pelasksanaan penggunaan, pemanfaatan, penghapusan, dan pemindahtanganan barang milik negara. ${ }^{11}$ Untuk membuat perjanjian BOT terdapat beberapa langkah awal yang harus dilakukan yakni:

1) Tahap Pra kontrak (awal sebelum kontrak) diantaranya:

(a) Negosiasi

Negosiasi proses awal sebelum kontrak yang mencakup proses pertemuan, tawar-menawar dan penentuan objek kontrak antara para pihak yang berkepentingan dan memiliki tujuan yang sama sehingga timbulah kesepakatan yang bersifat keputusan antara kedua belah pihak. Segala

9 Soekanto, Soerjono, dan Sri Mamudji. Penelitian Hukum Normatif Suatu Tinjauan Singkat. (Jakarta: PT RajaGrafindo Persada, 2009), 56.

10 Muhammad Dzikirullah H. Noho. "Memaknai Hak Dan Kewajiban Dalam Kebijakan Kerjasama Swasta Dengan Pe,erintah Daerah (Pemda) Melalui Kerjasama Build Operate Transfer (BOT) Bidang Pasar". The Journal of Society and Media 3, No.1 (2018): 56

11 Ibid. 
informasi selama negosiasi berlangsung para pihak berhak mencatat dan memahaminya sebagai catatan awal serta dapat didokumentasikan.

(b) Desain Proyek

Desain proyek adalah sebuah perencanaan dasar yang dilakukan sebelum disepakati menggunakan perjanjian BOT terhadap alternative pertimbangan yang ada sekarang dan yang akan timbul nantinya. Pertimbangan yang dimaksud yaitu; pertimbangan khusus mengenai laba dan rugi dari pola investasi yang disepakati, pengakuan para pihak atas hak dan kewajiban dengan mengutamakan rasa aman serta nyaman dari penyandang dana untuk menempatkan dananya, serta peranan pemerintah dalam memberikan pengamanan melalui sistem birokrasi yang ada dan disesuaikan nantinya sebagai syarat administratif proyek tersebut. Contoh kemungkinan yang biasa terjadi seandaikan perencanaan awal desain proyek ini tidak dilakukan, apabila dari pemerintah tidak menyetujui untuk dilaksanakannya perjanjian BOT, maka tentu semua itu dapat dibatalkan atau sebaliknya akan dibuatkan lagi desain proyek yang baru agar pada tahap ini semua pihak yang berkepentingan terfasilitasi dengan baik dan tidak adanya tumpang tindih antara para pihak nantinya.

(c) Studi kelayakan (feasibility study)

Studi kelayakan digunakan sebagai data pendukung dan penunjang terlaksananya suatu proyek berdasarkan perjanjian BOT dilihat dari berbeda sudut pandang terutama tingkat kelayakan dan prospek dari suatu proyek, serta secara umum seperti: sektor proyek (keuangan, ekonomi, pemasaran, teknik) dan sektor lingkungan atau modal awal yaitu perijinan administratif (sosial budaya dan hukum). Hal ini memberikan hasil yang dibutuhkan bagi suatu proyek perlu atau tidaknya ada negosiasi kembali.

2) Tahap Kontrak

(a) Kelengkapan Dokumen

Tahap Kelengkapan Dokumen adalah menyiapkan semua data dalam sebuah draft dokumen yang diperlukan agar sesuai dengan kebutuhan sebelum dilaksanakannya suatu proyek pembangunan. Bentuk dari dokumen Proyek pembangunan berkaitan dengan tanah menggunakan model BOT memakai dokumen sederhana dengan bentuk "Perjanjian Sewa Menyewa", "Perjanjian Sewa Menyewa Tanah" dan "Perjanjian Pemakaian Tanah".

(b) Pengesahan Dokumen dengan tanda tangan

Pengesahan dokumen adalah dengan penandatangannan perjanjian BOT dapat dilakukan para pihak ditempat yang telah disetujui dan ditentukan dan dapat dilakukan oleh notaris dan lain pejabat lainnya. Apabila perjanjian telah ditandatangani, penyusunan proyek sampai dengan tahap penandatanganan telah selesai, berikutnya adalah pelaksanaan proyek.

3) Tahap selesai kontrak (pasca kontrak)

(a) Realisasi Perjanjian (Pelaksanaan)

Kata sepakat antara para pihak pada tahapan awal dibuatnya perjanjian sampai dengan penandatanganan sangat mudah untuk dicapai, namun pelaksanaan atau penerapan perjanjian itulah yang sangat penting dan sering kali terjadi masalah. Melaksanakan apa yang tertuang dalam perjanjian sangat penting, dikarenakan hal tersebut merupakan prestasi antara para pihak yang telah 
bersepakat. Adanya sanksi-sanksi yang diatur dalam setiap perjanjian adalah sebagai akibat yang akan diterima pihak yang melanggar atau tidak melaksanakan apa yang tertuang dalam perjanjian, sehingga diperlukannya iktikad baik dari para pihak. Pada aturan yang berlaku secara umum, Kitab Undang-Undang Hukum Perdata (KUHPerdata) menyebutkan adanya wanprestasi dan adanya sanksi batal atas perjanjian tersebut atau secara hukum batal, apabila unsur dari perjanjian tidak terpenuhi. Untuk itu agar perjanjian BOT dapat dilaksanakan, maka diperlukan model perjanjian kerjasama/ sewa menyewa BOT yang harus memperhatikan beberapa hal-hal khusus, yaitu meliputi:

1. Kondisi/status perusahaan, harus berbentuk badan hukum, bagi investor asing/domestik harus berdomisili dan berkedudukan di Indonesia serta didirikan berdasarkan peraturan perundang-undangan yang mengatur tentang badan hukum/perusahaan di negara Indonesia.

2. Tujuan usaha atau bidang usaha perusahaan dan ruang lingkup usaha harus disesuaikan dengan Undang-Undang No. 3 Tahun 1982 Tentang Wajib Daftar Perusahaan dan Peraturan Perundang-undangan yang mengatur tentang Perusahaan.

3. Kepemilikan saham/organ perusahaan haruslah jelas apakah merupakan kepemilikan perorangan atau terdapat badan usaha yang ikut tergabung dalam proyek kerjasama yang menggunakan model perjanjian BOT. Tujuannya agar jelas mengenai pembagian laba/deviden setelah proyek berjalan dan keuntungan yang didapatkan dari berjalannya perusahaan.

4. Perizinan

(i) Untuk segala penempatan modal (investasi), disesuaikan dengan ketentuan peraturan perundang-undangan berlaku.

(ii) Untuk investasi menggunakan tenggang waktu "operating permint" ditentukan dengan mempertimbangkan pada perjanjian mengenai investasi model bagaimana yang disepakati.

5. Memprioritaskan tenaga kerja lokal, jika melibatkan Tenaga kerja asing, maka harus memenuhi persyaratan yang ditentukan oleh Depertemen Tenaga Kerja (Depnaker) dan Badan Koordinasi Penanaman Modal (BPPM) yang mana nantinya akan digantikan dengan tenaga kerja lokal.

6. Pajak akan masuk ke kas negara sebelum pengoperasian ataupun pembangunan proyek. Pengenaan pajak harus disesuaikan dengan peraturan yang berlaku, antara lain Undang-Undang No. 16 Tahun 2000 tentang Perubahan Kedua Atas Undang-Undang No. 17 Tahun 2000 tentang Perubahan Ketiga atas Undang-Undang No. 7 tahun 1983 tentang Pajak Penghasilan dan Peraturan Pelaksanaannya. Kemudian dalam kaitannya dengan pertanahan disesuaikan dengan Undang-Undang No. 20 tahun 2000 tentang Perubahan atas Undang-Undang No. 21 Tahun 1997 tentang Bea Perolehan Hak atas Tanah dan Bangunan serta Peraturan Pelaksanaannya.

7. Harus memahami mengenai peraturan-perturan mengenai pertanahan. Adapun peraturan-peraturan itu diantaranya; Undang-undang No. 5 Tahun 1960 Tentang Peraturan Dasar Pokok-Pokok Agraria (UUPA); Peraturan Pemerintah Nomor 40 Tahun 1996 tentang Hak Guna Usaha (HGU), Hak 
Guna Bangunan (HGB) dan Hak Pakai (BP) atas Tanah.

8. Kontrak Konsesi bertujuan mengambil manfaat ekonomi dan mencari keuntungan yang digunakan untuk menutupi (mengganti) pembiayaan dari keseluruhan pembangunan. Selain itu investor berhak untuk mengoperasikan dan memelihara secara sepenuhnya dalam jangka waktu (ini disebut jangka waktu konsensi) serta menerima pendapatan dari investasi seluruhnya. Adapun dalam kontrak konsensi yang tercantum diantaranya :

a. Penjelasan secara jelas dan tegas mengenai hak konsesi yang bersifat eklusif pada umumnya yang tercantum dalam kontrak BOT, sehingga mengantisipasi adanya masalah monopoli pengelolaaan dan pengoperasian dan monopoli keuntungan dari proyek dengan BOT sampai sulit untuk diperoleh dan ribet dalam penyelesaiannya. Dengan demikian perlu adanya klausula yang jelas dalam BOT terhadap penggunan hak eksklusif/pemilik lahan tidak serta merta dapat dicantumkan dalam kontrak konsesi, apabila diperlukan harus dengan jelas.

b. Lingkup proyek, jangka waktu adalah hal terpenting dari pengoperasian karena berkaitan dengan berapa lama pengelolaan diberikan dan berapa lama pengembaliaan dari segala biaya-biaya yang dijadikan sebagai modal investasi serta segala kebutuhan yang diperlukan investor untuk itu harus dicantumkan dengan jelas dalam kontrak konsensi mengenai hal itu agar jelas memuat hal-hal yang dilarang dan diperbolehkan kepada investor.

c. Dukungan dan komitmen pemerintah, dukungan dari pemerintah diperlukan untuk meyakinkan antara pihak investor (swasta) dan pemerintah terhadap proyek pembangunan ini menggunakan kontrak BOT atau mengikat dan mengamankan proyek pembangunan itu diadakan antara, pemerintah dengan investor (swasta). Dukungan ini dituangkan secara jelas dalam kontrak konsensi sebagai komitmen pemerintah siap memberikan segala bantuan yang diperlukan dari sisi jaminan, peraturan perundang-undangan, peraturan pemerintah, terkecuali apabila ada perubahan struktur pemerintahan yang hanya dapat diberikan oleh pemerintahan yang baru.

d. Aspek keuangan, modal investasi atau penyandang dana (investor), pengelolaan keuangan dari adanya penempatan atau pemindahan dana dari mata uang asing ke bentuk mata uang yang diperlukan nanti, kemudian pengelolaan prioritas utama baik segala bentuk pajak-pajak dan perizinan yang timbul untuk keperluan administrasi pembangunan proyek bersangkutan.

e. Isi kontrak konsensi dapat dipertegas dengan menambahkan klausula tentang pengalihan pada operator lain. Pergantian operator dilakukan apabila terjadi kurang maksimalnya operator pertama dalam pengelolaan pembangunan proyek sehingga pemilik hak eksklusif (pemilik lahan) harus mampu memaksimalkan pengoperasiaan proyek yang bersangkutan.

f. Hak atas property, Pemerintah/pemilik lahan pada akhir masa konsensi yang ditentukan dapat memperoleh pengalihan Hak atas properti ini. 
(b) Penyelesaian Sengketa

Apabila terjadi sengketa, maka penyelesaian sengketa dalam perjanjian BOT ini diselesaikan secara keperdataan, karena hubungan yang timbul dari perjanjian ini bersifat kepentingan pribadi atas dasar kesepakatan yang dicantumkan dalam kontrak. Adapun bentuk penyelesaian sengketanya dapat dilakukan dengan dua cara, yaitu dengan proses pengadilan (litigasi) atau tanpa melalui proses pengadilan (non litigasi) yaitu mediasi dengan menunjuk pihak ketiga.

Berdasarkan uraian tersebut terkait hal-hal khusus yang harus diperhatikan dalam pembuatan perjanjian BOT dan pengaturan mengenai penyelesaian sengketa, adalah merupakan upaya untuk melindungi, memaksimalkan, dan menjamin dalam pelaksanaan proyek pembangunan dan meningkatkan efisiensi ekonomi. Secara Hukum, Perjanjian BOT berfungsi sebagai pedoman dasar untuk memberikan jaminan, kepastian hukum, melindungi serta memberikan kesimbangan antara para pihakpihak apabila ada yang bertentangan, tolak ukur dalam mewujudkan keamanan dan ketertiban yang umum dan melibatkan masyarakat dalam dinamika kehidupan. Hukum tidak sebatas asas dan kaidah yang berlaku akan tetapi hukum itu hidup dan berkembang menyesuaikan dinamika kehidupan mencakup masyarakat dan yang terkait, pada kenyataan kaidah itu bisa diwujudkan atas dasar keputusan dari lembaga-lembaga (Institutions) dengan segala proses-proses (Processes) dan mekanisme yang berbeda.

\subsection{Peran Notaris dalam Pembuatan Perjanjian Build Operate and Transfer (BOT)}

Perjanjian merupakan bagian hukum perikatan terbentuk atas dasar perjanjian itu sendiri atas dasar persetujuan/kesepakatan, dengan demikian perjanjian bisa disebut dengan kontrak dalam bentuk tertulis sehingga mengikat kedua belah pihak atau lebih yang ikut serta tercantum di perjanjian. ${ }^{12}$ Pasal 1313 KUHPerdata, menyebutkan "suatu perjanjian adalah suatu perbuatan dengan mana satu orang atau lebih mengikatkan dirinya terhadap satu orang lain atau lebih". Menurut Abdulkadir Muhammad menafsirkan persetujuan awal tumbulnya perjanjian, persetujuan dua pihak atau lebih sepakat terikat dalam perjanjian dengan tujuan bersama atas lapangan harta kekayaan atau perihal tertentu. ${ }^{13}$ Terdapat peristiwa hukum pada sebuah perjanjian, yang mana ada pihak berjanji kepada seorang atau lebih untuk melakukan sesuatu atau tidak. Adanya kesepakatan dalam berjanji itu maka, salah satu pihak berhak menerima hal yang diperjanjikannya itu oleh satu pihak begitupun sebaliknya. Sehingga pihak dalam perjanjian memiliki hak dan kewajiban sebagai prestasi (kewajiban) harus terpenuhi saat melakukan sebagaimana tertulis diperjanjian.

Perjanjian BOT dikatakan sah apabila sesuai secara umum sesuai dengan ketentuan sebagaimana diatur Pasal 1320 KUH Perdata, yaitu:

(a) Adanya kata setuju/sepakat untuk pihak yang terikat dalam perjanjian

(b) Cakap hukum

(c) Suatu hal tertentu sebagai tujuan dalam perikatan

(d) Sebab yang tidak bertentangan (halal) dengan ketentuan berlaku

Perjanjian BOT secara normatif tidak diatur secara khusus oleh Undang-Undang, namun pelaksanaan kontrak kerjasama oleh pemerintah ini dapat kita jumpai dalam Peraturan Pemerintah No. 27 Tahun 2014 tentang Pengelolaan Barang Milik Negara

12 Miru, Ahmadi. Hukum Kontrak. (Jakarta: PT Raja Grafindo Persada, 2018), 21.

13 Muhammad, Abdulkadir. Hukum Perjanjian. (Bandung: PT Alumni, 2010), 36. 
/Daerah, di mana Pasal 1 Ayat (14) dijelaskan bahwa "Pemanfaatan Barang Milik Negara/Daerah berupa tanah oleh pihak lain dengan cara mendirikan bangunan dan/atau sarana berikut fasilitasnya, kemudian didayagunakan oleh pihak lain tersebut dalam jangka waktu tertentu yang telah disepakati, untuk selanjutnya diserahkan kembali tanah beserta bangunan dan/atau sarana berikut fasilitasnya setelah berakhirnya jangka waktu." Setelah jangka waktu berakhir, maka sektor swasta menyerahkan kembali tanah beserta bangunan infrastruktur berikut fasilitasnya. Selanjutnya dari segi pemanfaatannya menurut Pasal 27 PP No. 27 Tahun 2014 tersebut menentukan, "Bentuk Pemanfaatan Barang Milik Negara/Daerah berupa: (a) Sewa; (b) Pinjam Pakai; (c) Kerja Sama Pemanfaatan; (d) Bangun Guna Serah atau Bangun Serah Guna; atau (e) Kerja Sama Penyediaan Infrastruktur." Selanjutnya mengenai pembuatan perjanjian BOT bisa diakomodir dengan perjanjian dibuat antara para pihak secara bawah tangan atau dibuat dihadapan notaris secara notarial. ${ }^{14}$

Notaris sebagai pejabat umum yang berwenang membuat akta autentik harus memiliki Integritas moral yang baik, ketelitian dan ketrampilan yang baik dalam membuat akta autentik yang sesuai dalam peraturan notaris. Tanggung jawab notaris sebagai profesi lahir dari adanya kewajiban dan kewenangan yang diberikan kepadanya, kewajiban dan kewenangan tersebut secara sah dan terikat mulai berlaku sejak notaris mengucapkan sumpah jabatannya sebagai notaris. Sumpah yang telah diucapkan tersebutlah yang seharusnya mengontrol segala tindakan notaris dalam menjalankan jabatannya. ${ }^{15}$

Akta yang dibuat dihadapan atau oleh notaris berkedudukan sebagai akta otentik menurut bentuk dan tata cara yang ditetapkan Undang Undang Jabatan Notaris, hal ini sesuai dengan pendapat Philipus M. Hadjon, bahwa syarat akta otentik yaitu: (a) Dibuat dalam bentuk yang ditentukan oleh Undang-Undang (bentuknya baku); (b) Dibuat oleh dan di hadapan Pejabat Umum. Selain itu menurut Irawan Surodjo, bahwa ada 3 (tiga) unsur esensial agar terpenuhinya syarat formal suatu akta otentik, yaitu (a) Dibuat dalam bentuk yang ditentukan Undang-Undang; (b). Dibuat oleh dan dihadapan Pejabat Umum; (c) Akta yang dibuat oleh atau dihadapan Pejabat Umum yang berwenang untuk itu dan ditempat di mana akta itu dibuat. ${ }^{16}$

Terkait pembuatan perjanjian BOT, Notaris memiliki peran sebagai penerima, pendengar, serta mencatat dengan baik sebelum memformulasikan segala bentuk, tata cara, dan keinginan para pihak sebelum dibuatkan dalam akta, sehingga pembuatan perjanjian BOT segala kebutuhan dan keinginan para pihak bisa terealisasikan secara tertulis, adil dan tidak menimbulkan keberpihakan atau terjadinya perjanjian tidak seimbang atau condong menguntungkan satu pihak saja. Sebagaimana diuraikan diatas bahwa Notaris hanya memformulasikan kehendak para pihak kedalam akta. Akta Notaris merupakan perjanjian para pihak yang mengikat mereka membuatnya, oleh karena itu syarat-syarat sahnya suatu perjanjian harus dipenuhi. ${ }^{17}$

14 Disemadi, Hari Sutra. "Kontrak Build Operate Transfer Sebagai Sarana Mewujudkan Kesejahteraan Rakyat". Jurnal Komunikasi Hukum 5, No. 2 (2019): 133.

15 Ivan Chairunanda Kusuma Putra. "Perlindungan Hukum Notaris Terhadap Perjanjian Perikatan Jual Beli yang Diikuti Dengan Adanya Pengakuan Hutang". Lex Renaissance 3, No.2 (2018): 385.

16 Adjie, Habib. Hukum Notaris Indonesia, Tafsir Tematik terhadap UU No. 30 Tahun 2004 tentang Jabatan Notaris. (Bandung: Refika Aditama, 2011), 33.

17 Prananda, Vitto Odie \& Ghansham Anand. "Perlindungan Hukum Terhadap Notaris Atas Pembuatan Akta Oleh Penghadap Yang Memberikan Keterangan Palsu". Jurnal Elektronik: Hukum Bisnis 2, No. 2 (2018): 9. 
Notaris juga harus mencatat segala hal yang menjadi negosiasi para pihak, setelah kesepakatan antara para pihak tercapai apabila diperlukan klausul khusus yang diinginkan maka, notaris harus mencantumkannya secara jelas, sehingga kekuatan mengikat perjanjian itu lebih kuat karena para pihak yang menginginkannya tidak sebatas klausula baku dalam perjanjian. Klausula-klausula itu tertulis dalam perjanjian sehingga semua pihak perjanjian ini memiliki hak dan kewajiban (prestasi) yang secara sah telah disepakati bersama serta dilaksanakan dengan sukarela. Hak serta Kewajiban para pihak di perjanjian itu haruslah seimbang karena jika dikemudian hari terjadi kendala atau dengan sengaja ada pihak yang tidak melaksanakan apa yang disepakati maka, sudah cukup jelas pihak melanggar yang telah diperjanjikannya dapat telah ingkar janji (wanprestasi).

Pembuatan akta dari notaris, hal yang pertama kali harus dilakukan adalah memang benar kenal dan paham tentang maksud dan tujuan para pihak sebagai antisipasi kemungkinan permasalahan yang timbul dikemudian hari. Perancangan akta perjanjian BOT sama dengan perjanjian pada umumnya yang dibuat dihadapan notaris, yang terpenting perjanjian itu mengakomodasi seluruh kepentingan para pihak dengan seimbang dan jelas memberikan jaminan guna kepastian hukum sampai terealisasi dengan baik dan definitif. Sehingga keotentikan akta notaris kuat dan terjaga karena telah dibuat secara teliti dan sangat jelas untuk mengantisipasi kemungkinan resiko yang terjadi dikemudian hari dalam perjanjian BOT ini.

Perjanjian yang telah ada terkadang tidak bisa terlepas dari adanya permasalahan, berpotensi konflik, termasuk perjanjian BOT ini selalu ada kemungkinan berpotensi konflik sengaja ataupun tidak sengaja. Sewajarnya permasalahan sengketa dan perselisihan biasa timbul karena interpersonal kurang baik para pihak dalam perjanjian atau secara badan hukum dalam bidang bisnis dan usaha diluar ataupun dalam perjanjian, seperti kesalahpahaman, pelanggaran atas larangan tertentu, wanprestasi (ingkar janji), terdapat kepentingan yang bergesekan sampai menimbulkan kerugian para pihak atau salah satu. Sumber konflik yang secara umum sering terjadi dalam suatu perjanjian sehingga menjadi sengketa adalah: keinginan yang tidak baik dari satu pihak, kurang telitinya mencantumkan bahasa sebagai kalimat klausula dalam kontrak, keadaan diluar kemampuan (Force Majeure), ingkar janji (wanprestasi), kekeliruan waktu dan sanksi/denda, dan masalah lain antara para pihak dalam perjanjian.

Peranan Notaris dalam pembuatan perjanjian BOT adalah sebagai professional dan sebagai pejabat umum yang bertugas dan berwenang untuk membuat akta otentik dan juga untuk menjaga agar pedoman hukum berlaku. Selain itu juga Notaris adalah pihak yang yang netral dan berada ditengah-tengah antara para pihak yang berkepentingan. Oleh karena seorang notaris sangat diperlukan dalam perjanjian BOT ini, maka Notaris juga harus mampu memberikan saran dan memformulasikan segala keinginan pihak menjadi poin-poin penting dalam suatu perjanjian tertulis dan notarial. Notaris harus mampu memberikan prediksi atau kemungkinan peristiwa dikemudian hari yang biasa terjadi dari apa yang dikehendaki para pihak sehingga terhindar dari adanya sengketa. Apabila tetap terjadinya permasalahan dikemudian hari, Notaris sebagai pihak netral dapat membantu memberikan alternatif penyelesaian sengketa perjanjian tersebut, dengan memberikan gambaran jelas mengenai mekanisme penyelesaian konflik antara para pihak, dimana konflik masalah dapat diselesaikan secara mediasi (musyawarah), namun apabila gagal menemukan solusi, masalah bisa diajukan ke aparatur hukum dan diselesaikan dimata hukum yang berlaku, yaitu melalui pengadilan (litigasi). 


\section{Kesimpulan}

Berdasarkan hasil dan pembahasan diatas kesimpulan dalam penulisan ini adalah pembuatan perjanjian BOT antara pihak Badan Usaha Milik Negara (BUMN) dengan pihak swasta harus melalui beberapa tahap, yakni tahap awal kontrak (prakontrak), tahap kontrak dan tahap selesai kontrak (pasca kontrak). Adapun peranan Notraris pada pembuatan perjanjian BOT adalah sebagai pihak ditengah atau netral dan memberikan saran kepada pihak untuk menuangkan keinginannya dalam bentuk perjanjian.

\section{DAFTAR PUSTAKA}

Buku:

Adjie, Habib. Hukum Notaris Indonesia, Tafsir Tematik terhadap UU No. 30 Tahun 2004 tentang Jabatan Notaris. (Bandung: Refika Aditama, 2011).

Miru, Ahmadi. Hukum Kontrak. (Jakarta: PT Raja Grafindo Persada, 2018).

Muhammad, Abdulkadir. Hukum Perjanjian. (Bandung: PT Alumni, 2010).

Sjahdeini, Sutan Remy. Kebebasan Berkontrak dan Perlindungan yang Seimbang bagi Para Pihak dalam Perjanjian Kredit Bank di Indonesia. (Jakarta: Pustaka Utama Grafiti, 2009).

Soekanto, Soerjono, dan Sri Mamudji. Penelitian Hukum Normatif Suatu Tinjauan Singkat. (Jakarta: PT RajaGrafindo Persada, 2009).

\section{Jurnal:}

Adha, Lalu Hadi. "Kontrak Buld Operate Transfer Sebagai Perjanjian Kebijakan Pemerintah Dengan Pihak Swasta". Jurnal Dinamika Hukum 1, No. 3 (2011).

Disemadi, Hari Sutra. "Kontrak Build Operate Transfer Sebagai Sarana Mewujudkan Kesejahteraan Rakyat". Jurnal Komunikasi Hukum 5, No. 2 (2019).

Ivan Chairunanda Kusuma Putra. "Perlindungan Hukum Notaris Terhadap Perjanjian Perikatan Jual Beli yang Diikuti Dengan Adanya Pengakuan Hutang". Lex Renaissance 3, No.2 (2018).

Kamilah, Anita. "Kedudukan Perjanjian Bangun Guna Serah (Build Operate And Transfer/BOT) Dalam Hukum Tanah Nasional". Jurnal Ilmu Hukum Litigasi 15, No.1 (2014).

Masitoh, Hidayatul. "Public Private Partnership (PPP) Pengelolaan Aset Daerah: Studi Deskriptif Tentang Kemitraan Antara Perusahaan Daerah Pasar Surya (PDPS) Surabaya Dengan PT Arwinto Intan Wijaya (AIW) Dalam Pembangunan Dan Pengembangan Darmo Trade Centre (DTC) Surabaya." Jurnal Kebijakan Dan Manajemen Publik 2, No.1 (2014)

Muhammad Dzikirullah H. Noho. "Memaknai Hak Dan Kewajiban Dalam Kebijakan Kerjasama Swasta Dengan Pemerintah Daerah (Pemda) Melalui Kerjasama Build Operate Transfer (BOT) Bidang Pasar". The Journal of Society and Media 3, No.1 (2018)

Nurjamil \& Siti Nurhayati. "Build Operate And Transfer Agreements (BOT) On The Use Of Productive Waqf Hak Guna Bangun (HGB) In The National Islamic Economic Law Development" Al-Awqaf: Jurnal Wakaf dan Ekonomi Islam 11, No. 2 (2018).

Prabawa, I Gede Abdhi. "Kajian Hukum Terhadap Perjanjian Build Operate And Transfer (BOT) Untuk Melindungi Hak Milik Atas Tanah Dalam Rangka 
Menunjang Sektor Pariwisata". Kumpulan Jurnal Mahasiswa Fakultas Hukum 1, No. 1 (2014).

Prananda, Vitto Odie \& Ghansham Anand. "Perlindungan Hukum Terhadap Notaris Atas Pembuatan Akta Oleh Penghadap Yang Memberikan Keterangan Palsu". Jurnal Elektronik: Hukum Bisnis 2, No. 2 (2018).

Ramadhani, Rahmat. "Konstruksi Hukum Kepemilikan Bangunan Di Atas Tanah Hak Milik Orang LainBerdasarkan Perjanjian Build Operate And Transfer (BOT)". Jurnal EduTech 4, No. 1 (2018).

\section{Peraturan Perundang-Undangan :}

Kitab Undang-Undang Hukum Perdata (Staatsblad Tahun 1847 Nomor 23).

Undang-undang No. 5 Tahun 1960 Tentang Peraturan Dasar Pokok-Pokok Agraria (UUPA) Lembaran Negara Republik Indonesia Tahun 1960 Nomor 104, Tambahan Lembaran Negara Republik Indonesia Nomor 2043).

Undang-Undang Nomor 18 Tahun 1999 Tentang Jasa Konstruksi (Lembaran Negara Republik Indonesia Tahun 1999 Nomor 54, Tambahan Lembaran Negara Republik Indonesia Nomor 3833).

Undang-Undang Nomor 10 Tahun 2009 tentang Kepariwisataan (Lembaran Negara Republik Indonesia Tahun 2009 Nomor 11, Tambahan Lembaran Negara Republik Indonesia Nomor 4966).

Peraturan Pemerintah Nomor 40 Tahun 1996 tentang Hak Guna Usaha (HGU), Hak Guna Bangunan (HGB) dan Hak Pakai atas Tanah. Lembaran Negara Republik Indonesia Tahun 1996 Nomor 58, Tambahan Lembaran Negara Republik Indonesia Nomor 3643). 